\title{
Dnister pspp base GNSS network optimization
}

\author{
$\underline{\text { Mychailo Duma }^{1}}$ \\ 1. Department of Higher Geodesy and Astronomy, National University "Lviv Polytechnic", Ukraine, Lviv, Str. \\ Bandera 12, E-mail: duma.myk@gmail.com
}

\begin{abstract}
The goal of this study is the development of conceptual frameworks and proposals to optimize the geometry of Dnister PSPP base GNSS network and to identify ways for improving the accuracy of GNSS measurements for maximum control.
\end{abstract}

Keywords - D - criterion, GNSS network, the geometric configuration, Dnister PSPP, GNSS network.

\section{Introduction}

In 2003 to support construction and observation of strains slopes near major hydropower plants was created Dnister PSPP base GNSS network. Laid network consisted of 15 points, conventionally divided into a framework and a working network, which respectively numbered 7 and 8 points $[6,4]$. Since 2004 , the network points held periodic static satellite measurements (seasonal cycle). The analysis and processing of measured data revealed that the mean square error (MSE) determining the coordinates do not exceed $2 \mathrm{~mm}$ - for forced centering points and 3 $\mathrm{mm}$ - for points from centering on the tripod [6]. This methodology is considered a classic by satellite measurements. The principle which is conducted simultaneously measuring between two or more fixed GNSS receiver. Duration of observations depends on the length of the measured lines, while the number of visible satellites, such as receivers and the required accuracy. This methodology is widely used to monitor a number of Ukrainian HPP, Kyiv HPP (2003, 2004 Ukrynzhheodezyya 2009 - PE "InjGeo"); Kaniv HPP (May, October 2007, 2010 - NU"LP"); Kremenchug HPP (2000, 2001 - Ukrynzhheodezyya, 2007 - NU"LP"); Dniprodzerzhynsk HPP (May, October, 2007 - NU"LP"); Dnipro HPP (1997 (2 cycles) - Ukrynzhheodezyya, 2005, 2010 - NU"LP") [1]. It should be noted that during the period of data objects for the accuracy of the horizontal displacement is $2 \mathrm{~mm}$, and vertical - $3 \mathrm{~mm}$. In the [GPS Technology Used in Three Gorges Reservoir Landslide Deformation Monitoring, Liu et al., 2008] presented using this methodology to monitor displacement in the world's most powerful HPP Three Gorges (China). The use of static methodology provided the coordinates accuracy - $1 \mathrm{~mm}$.

The analysis confirms the feasibility of multi days satellite measurements and their subsequent post-processing in specialized software. However, the use of this observation methodology imposes certain requirements on the geometry of the network, a bookmark geodetic points and their location on the ground.

Dnister PSPP base GNSS network was expanded and detailed during the station construction (Fig. 1), so now there are 43 observation points on the studied area [3].

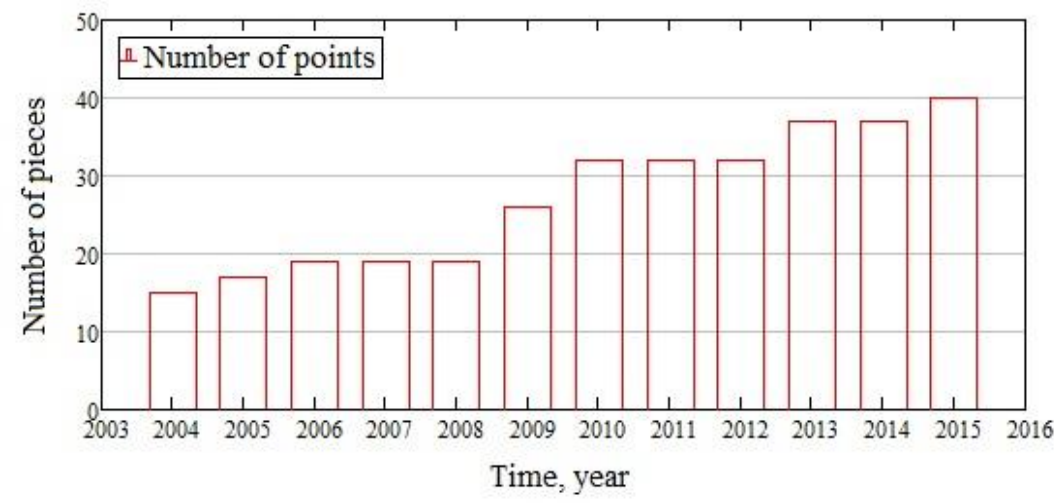

Fig. 1. The process of detailing and expanding of Dnister PSPP base GNSS network 
However, the process of detailing and expanding of Dnister PSPP base GNSS network was conducted without design and optimization methodology. The result is that this network is significantly extended northward along the Dnister and is not balanced; density of points is not the same; a significant number of points are weak, because of poor satellites visibility and so on. In this regard for qualitative detection and consideration of these factors impact requires Dnister PSPP base GNSS network periodical analysis of problem areas and clarification of point's configuration. These measures will provide the best result.

\section{Methodology}

One of the main surveyor's objectives is to determine the spatial position of the points placed on different objects. The set of points designed to determine the spatial object position is called geodetic network. According to [8] all the points in the geodetic network can be divided into three groups: deformation, reference, orientation. The points in each group are located according to the shape, size, topographical and geological features of monitoring object. According to [9] there are four designing and optimization stages of geodetic networks for different purposes.

Structural optimization methodology of geometric network configuration using mathematical modeling consists of 3 interconnected blocks (Fig. 2.).

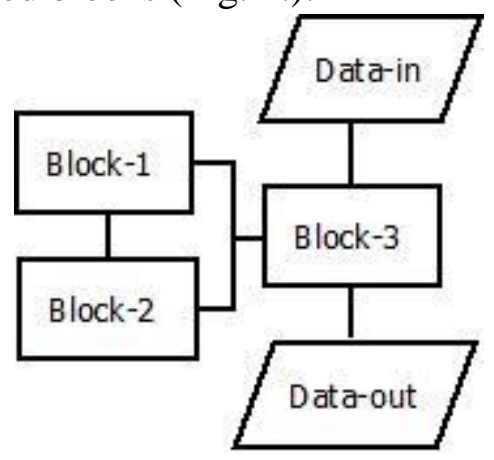

Fig. 2. The relationship between the blocks of methodologies of optimization geometric network configuration

Block-1: Calculation of optimization criteria. This block is designed to adjust measurements in a given network with parametric method and calculate determinant of covariance matrix. In this block is being formed parametric matrix $\mathrm{A}$ and weights matrix $\mathrm{P}$, based on the input data. We use obtained results to calculate covariance matrix $Q=\left(A^{T} P A\right)^{-1}$. Then we calculate determinant of covariance matrix $D=\operatorname{det}(Q)$.

Block 2: We calculate the movement direction of each point in which is observed the decreasing of optimization criteria. This block is designed to determine for each network point the optimal direction in which is observed values decreasing of optimization criteria. We use gradient method to search this direction. Gradient method is based on the finding of increases determinant of covariance matrix:

$$
\begin{aligned}
& \nabla x_{i}=\frac{F\left(x_{i}+l, y_{i}\right)-F\left(x_{i}-l, y_{i}\right)}{2 \cdot l}, \\
& \nabla y_{i}=\frac{F\left(x_{i}, y_{i}+l\right)-F\left(x_{i}, y_{i}-l\right)}{2 \cdot l}
\end{aligned}
$$

where $x_{i}$ and $y_{i}$-are initial coordinates of $i$ - th network point; $l$ - is constant which changed every coordinate (in this methodology is recommended to use 1 meter); $F(x, y)$ - objective function to calculate the determinant of the network.

We base on predefined gradients our further calculations of movement directions in each 
point, at which is observed the decrease of optimization criteria:

$$
\operatorname{tg}\left(\alpha_{i}\right)=\frac{\nabla y_{i}}{\nabla x_{i}}
$$

Block-3: Finding global minimum of the function and output of optimal geodetic network coordinates. This block is designed for consistent point's movement in a given direction (3) and calculation of optimization criteria for new point's locations.

$$
\begin{aligned}
& x_{i}^{I}=x_{i}+S_{i}^{I} \cdot \cos \left(\alpha_{i}\right), \\
& y_{i}^{I}=y_{i}+S_{i}^{I} \cdot \sin \left(\alpha_{i}\right),
\end{aligned}
$$

where $S_{i}^{I}$ - the distance at which point moves in a given direction. As point can move toward a given direction to infinity, the optimization problem can lose meaning. In this regard, the optimization process is restricted (radius within which you can move the point $-R$ ), as a result objective function becomes:

$$
\Phi(x, y)=F(x, y)+k\left\{\begin{array}{l}
\left(S_{i}^{I}-R_{i}\right) \leq 0 \Rightarrow \quad k=0, \\
\left(S_{i}^{I}-R_{i}\right) \triangleright 0 \Rightarrow k=\left(S_{i}^{I}-R_{i}\right) \cdot m
\end{array}\right.
$$

where $m-$ a constant that depends on the number of points in the network.

Further we find global minimum of the obtained objective function (4) and coordinate output for optimal geodetic network.

\section{Results}

There were highlighted 3 key problem groups of points for Dnister PSPP base GNSS network, as a result of points inspection on the ground, as well as detailed analysis of conducted and processed measurements.

Points with poor reception of satellite signal: GZ-10, GZ-11A, GZ-11B, GZ-12 (all water outlets of the system), Portal-2, Nyzhniy, OZS-1-1 and OZS-23-2 (all in northeastern slope). GNSS measurements on these points are in adverse conditions: closed horizon building and technological structures, landscape and vegetation, as well as high multipath, which lead to increased errors, coordinate determination. These points are installed on the northeastern slope, are not critical and important because we believe that they can be excluded from the application of GNSS measurements, because they degrade the accuracy of the overall network. Instead, points are installed on the system water outlets require constant precision control, so we offer them to determine the horizontal displacement of joint satellite, angular and linear measurements.

Points with centering tripod: PP-221 and PP-100. Centering on a tripod introduces additional systematic errors in the coordinates of the points. To improve the accuracy would be desirable to replace these points for points with forced centering.

Points damaged during construction Obryv and OGZ-1. Point Obryv was damaged by strengthening the slope in 2014, and point OGZ-1 was damaged by the movement of the road in 2016. To improve the accuracy would be desirable to replace these points with new ones.

In addition to points that must be removed or replaced in the analysis were identified additional areas that need monitoring. From the crowd, four such areas (the first on the northwest slope, first on the northeast slope, the second on the east side of the buffer reservoir) which you need to install new points to improve rigidity and accuracy of Dnister PSPP base GNSS network. The work area believed plane limited range of specified radius at any point in which to establish a new point. The size of the zone directly dependent on terrain conditions and the availability of nearby buildings, which have carried a negative impact on the quality of measurements. Figure 
3a presents the scheme of the existing groups of points, and the search area best position new points of Dnister PSPP base GNSS network.

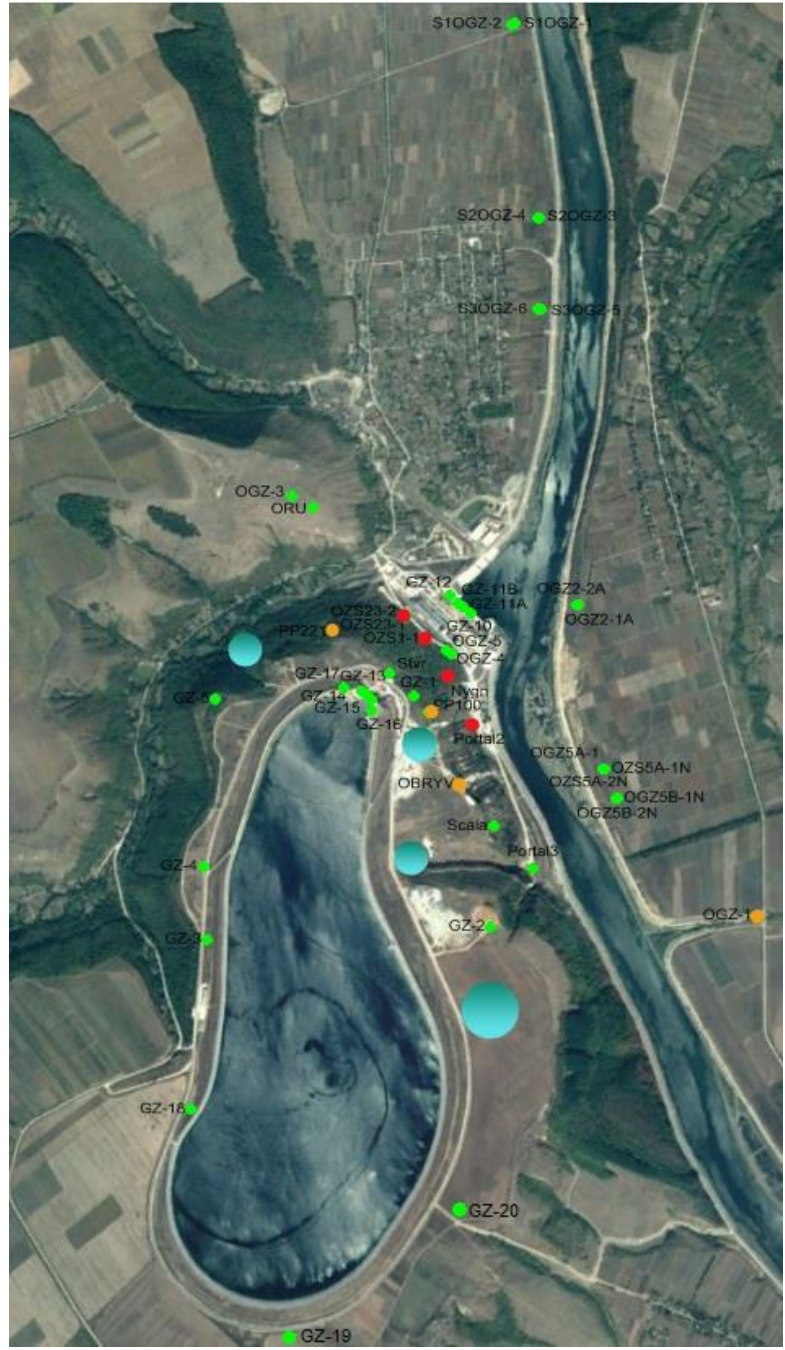

a) before optimization

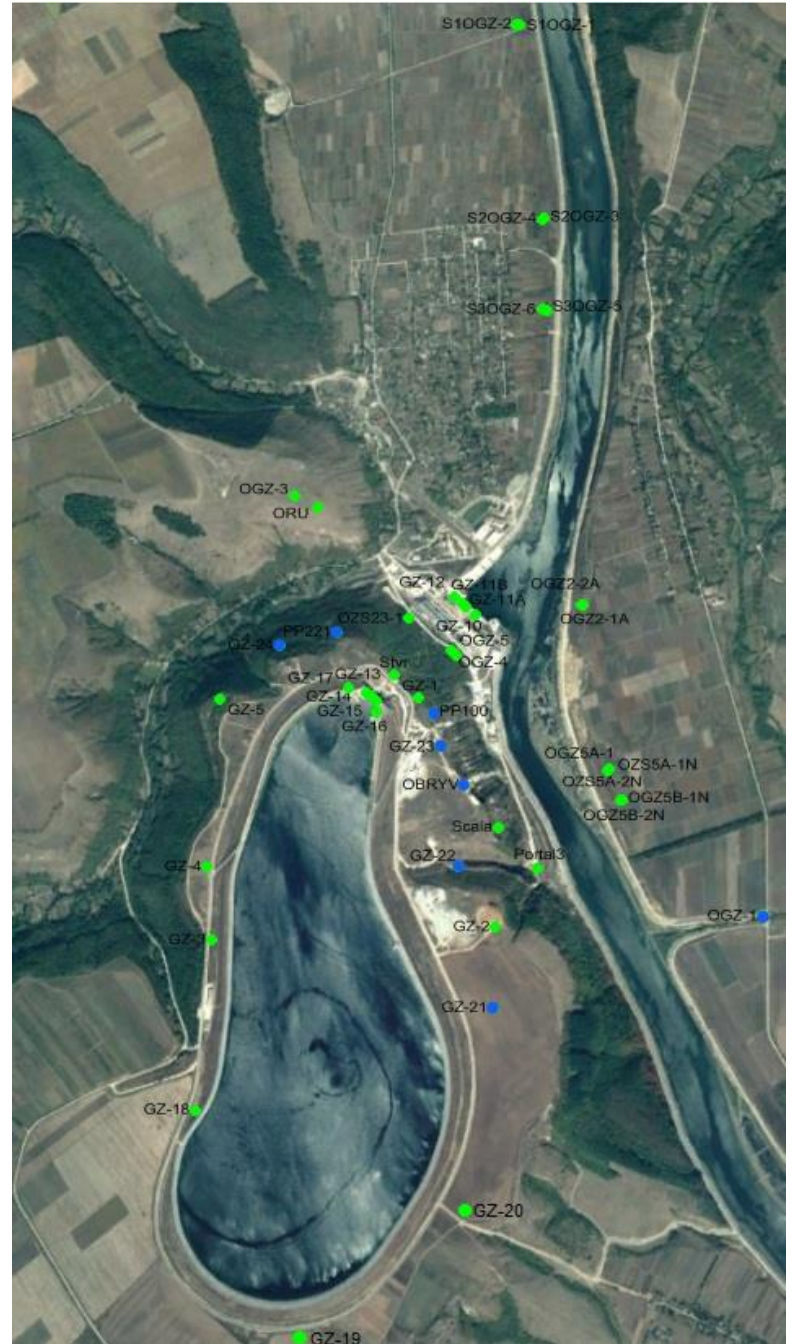

б) after optimization

Fig. 3. Scheme of points of Dnister PSPP base GNSS network $(-$ good points of the network; - bad points of the network; - points of the network, that need to be replaced; - zone of finding the optimal position for new points of the network; - new points of the network)

Thus, the analysis has found that to improve rigidity and accuracy of Dnister PSPP base GNSS network should:

exclude the application of 4 GNSS measuring points (Portal-2, Nyzhniy, OZS-1-1 and OZS23-2);

strengthen joint satellite angular and linear measurements 4 points (GZ-10, GZ-11A, GZ11B, and GZ-12);

replace existing 4 points (PP-221, PP-100, Obryv and OGZ-1);

establish 4 new points (GZ-21, GZ-22, GZ-23 and GZ-24).

It was revealed in this regard that 8 points of Dnister PSPP base GNSS network require optimization. For the optimization was used proposed optimization methodology for geometric configuration of network using mathematical modeling for evaluating the accuracy. According to the proposed methodology for replacement of existing zones and establish new points limited circles of a given radius. Since existing points that you want to replace the good location, then they selected zone radius of 10 meters. To find the best position new points GZ-22, GZ-23 and GZ-24 selected zone radius of 20 meters, while for a point GZ-21 - a radius of 30 meters. The 
main parameters are selected, the radius of terrain conditions and the availability of nearby buildings. As a result, of optimizing were installed new optimum points of Dnister PSPP base GNSS network (Fig. 3b).

We have conducted a priori assessment of accuracy to test the optimized Dnister PSPP base GNSS network. Observations should be made, according to [5], in the network by seasonal cycles, each cycle has 3 measurement sessions at each point. Given that the vectors of Dnister PSPP base GNSS network do not exceed 10 kilometers, the duration of the measurements at each point according to previous studies must be at least 6 hours [2, 7]. So, in these network in each cycle is measured about one-third of all possible vectors. In this regard, for a priori assessment of all possible vectors automatically selected amount determined by dependence $\frac{n \cdot s}{k} \cdot c$, where $n$-number of points in the network; $s$-number of sessions at each measurement point; $k$-the number of available GNSS receivers; $c$ - the number of vectors measured in the same session. The observation in the network was carried out using 5 to 7 GNSS receivers, so priori accuracy evaluation was conducted for these amounts. Table 1 presents a priori mean square errors (MSE) of coordinates determining of the network points before and after optimization.

Table 1

Priori mean square error of determining the coordinates of the network before and after optimization

\begin{tabular}{|c|c|c|c|}
\hline \multirow{2}{*}{$\begin{array}{c}\text { Number of } \\
\text { GNSS receivers, } \\
\text { pc. }\end{array}$} & \multicolumn{2}{|c|}{$\begin{array}{c}\text { MSE determine of the network } \\
\text { coordinates }\end{array}$} & $\begin{array}{c}\text { MSE improving of } \\
\text { determination of the } \\
\text { points coordinates , } \%\end{array}$ \\
\cline { 2 - 4 } & $\begin{array}{c}\text { before } \\
\text { optimization, } \mathrm{mm}\end{array}$ & $\begin{array}{c}\text { after optimization, } \\
\mathrm{mm}\end{array}$ & 8.3 \\
\hline 5 & 2.4 & 2.2 & 9.1 \\
\hline 6 & 2.2 & 2.0 & 10.0 \\
\hline 7 & 2.0 & 1.8 & \\
\hline
\end{tabular}

We have analyzed the results shown in Table 1 and can note that the value of the MSE priori determination of the coordinates of network points dropped after the network optimization. It was established that the optimization of Dnister PSPP base GNSS network will improve accuracy by $8.3-10.0 \%$ depending on the number of used GNSS receivers. We should take into account that Dnister PSPP base GNSS network had 43 points, and in the optimization process: 4 weak points were removed, 4 new points were installed and position of 4 existing points was minimally modified, the resulting value of network improving can be considered as good.

In summary we can say that the optimization of Dnister PSPP base GNSS network fully confirms the efficiency of the optimizing methodology of the network geometric configuration using mathematical modeling.

\section{Conclusion}

We developed the methodology for optimizing the geometric configuration of network using mathematical modeling.

There were highlighted 3 key problem groups of points for Dnister PSPP base GNSS network, as a result of points inspection on the ground, as well as detailed analysis of conducted and processed measurements: points with poor reception of satellite signal; points with centering 
tripod; points damaged during construction.

To exclude the application of 4 GNSS measuring points (Portal-2, Nyzhniy, OZS-1-1 and OZS-23-2); strengthen joint satellite angular and linear measurements 4 points (GZ-10, GZ-11A, GZ-11B and GZ-12); replace existing 4 points (PP-221, PP-100, Obryv and OGZ-1) and set a new 4 points (GZ-21, GZ-22, GZ-23 and GZ-24). To install the new points highlighted four areas that need monitoring.

Optimization of Dnister PSPP base GNSS network using the developed methodology resulted in improved accuracy for 8.3-10.0\% depending on the amount of used GNSS receivers.

\section{References}

[1] Bisovetskiy Yu., Tretyak K., Shchuchik E. Avtomatizatsiya geodezicheskikh nablyudeniy za gidrotekhnicheskimi sooruzheniyami gidroelektrostantsiy Ukrgidroenergo [Automation of geodetic observations of hydraulic structures of «Ukrhydroenergo» hydroelectric power stations], Gidroenergetika Ukraïni [Hydropower of Ukraine], 2011, no. 2, pp.45-51.

[2] Galaganov O., Guseva T., Labuntsova L. Geodinamichniy monitoring iz zastosuvannyam suputnikovikh tekhnologiy deyakikh rayoniv AYES [Geodynamic monitoring using satellite technology some nuclear areas], Zbirnik materialiv IKh-go mizhnarodnogo naukovotekhnichnogo simpoziumu "Geoinformatsiyniy monitoring navkolishnogo seredovishcha [Proceedings of the IX-th International scientific and technical symposium "Geoinformation monitoring of environment], 2004. - pp. 46-48.

[3] Duma M., Savchin I. Optimizatsiya konfiguratsii ta rozmishchennya punktiv opornoï GNSSmerezhi Dnistrovskoï GAYeS [Optimizing configuration and placement of items GNSS reference network Dniester PSP], Mizhnarodna Naukovo-Tyekhnichna Konfyeryentsiya Molodikh Vchyenikh «GeoTerrace-2016» [Conf. proc. International Scientific Conference of Young Scientists «GeoTerrace-2016»], 2016, pp.68-71.

[4] Sidorov I., Periy S., Sarnavskiy V. Viznachennya rukhiv zemnoï poverkhni v rayoni Dnistrovskoï GAYES suputnikovimi ta nazemnimi metodami [Determination of the earth surface movements in areas of Dniester GNSS using satellite and ground geodetic methods], Geodinamika [Geodynamics], 2015, no.pp.15-25.

[5] Tretyak K., Sidorov I. Optymizacija pobudovy geodezychnoi' merezhi Dnistrovs'koi' GAES suputnykovymy radionavigacijnymy tehnologijamy [Optimization of building geodetic network of the Dniester HPPS satellite radio navigation technologies]. Suchasni dosjagnennja geodezychnoi' nauky ta vyrobnyctva [Modern achievements in geodetic science and industry]. Lviv: Lviv Polytechnic Publishing House, 2005, pp. 207-219.

[6] Tretyak K., Sidorov I. Sumisne opratsyuvannya suputnikovikh i nazemnikh geodezichnikh vimiriv visokotochnoï merezhi budivnitstva Dnistrovskoï GAYES [Co-processing of satellite and ground-based measurements of high precision geodetic network construction of the Dniester PSP], Visnik geodeziii ta kartografiï [Journal of Geodesy and Cartography], 2012, no. 3(78), pp.6-9.

[7] Tretyak K. Planuvannya ta optimizatsiya GPS - vimiriv u geodezichnikh merezhakh [Planning and optimization of GPS - measurements in geodetic networks], Visnik geodeziï ta kartografiï [Journal of Geodesy and Cartography], 2000, no. 3(18), pp.7-13.

[8] Berne' J., Baselga S. First-order design of geodetic networks using the simulated annealing method, Journal of Geodesy, 2004, no. 78, pp. 47-54.

[9] Grafarend E. Optimization of geodetic networks, Bolletino di Geodesia a Science Affini, 1974, no. 33, pp. $351-406$. 